\title{
$\$$
}

\section{Regte, gesag en waardes}

\author{
Francois Venter \\ Departement Publiekreg \& Regsfilosofie \\ Potchefstroomse Universiteit vir $\mathrm{CHO}$ \\ POTCHEFSTROOM \\ E-pos: prffv@puknet.puk.ac.za
}

\begin{abstract}
Rights, authority and values

In view of Johan van der Vyver's immense contribution to the clarification of the meaning of legal concepts, the establishment of terminology, the analysis of doctrines and the explanation of the foundations of matters, it is considered appropriate in this article to revisit a question which has occupied jurists since time immemorial, namely what a right might be.

This question cannot be addressed without dealing with the context in which it stands. Therefore the fate of the doctrine of subjective rights is firstly traced, after which the phenomena of human rights and fundamental rights are discussed. Following these analyses, the question whether a single, comprehensive concept of right is viable is considered.

In this context the need for the legal scholar to thoroughly consider the origin or justification for the existence of government authority is motivated. It seems as though unanimity about a concept of right at anything beyond a relatively superficial, mechanical level is not really possible, but that a meaningful scholarly discourse on the matter is possible, at least among scholars who acknowledge the determining role of unverifiable presuppositions in the practice of scholarship.

Finally $i t$ is argued that there is a connection between the values of the Constitution, the exercise of government authority and the development of a South African concept of right.

Johan van der Vyver is 'n wetenskaplike met 'n sin vir orde. Deur die loop van sy veel geskakeerde publikasieloopbaan het hy heelwat insette gelewer oor die ordening van konsepte, die vestiging van terminologie, die ontleding van leerstukke en die verklaring van die grondslae van dinge. Derhalwe is dit aangewese om met hom as jubilaris in gedagte, weer te besin oor 'n vraag wat juriste sedert die aanvang van denke oor die reg onophoudelik teister, naamlik wat ' $n$ reg nou eintlik is
\end{abstract}


Hierdie vraag kan nie aangedurf word sonder die hantering van die konteks waarin dit staan nie. Gevolglik word eers die lot van die subjektiewe regsleer (in 2 hieronder) onder die loep geneem, en daarna menseregte en fundamentele regte in 3 , voordat die vraag na die bestaanbaarheid van 'n enkele, omvattende reg-begrip in 4 oorweeg word. Hier word die noodsaak vir die regswetenskaplike om die herkoms of regverdiging vir die bestaan van owerheidsgesag grondig te oorweeg, aan die orde gestel. Daaruit blyk dit dat eenstemmigheid op meer as 'n betreklik oppervlakkige, meganiese vlak oor 'n reg-begrip nie werklik moontlik is nie, maar dat 'n sinvolle wetenskaplike gesprek daaroor ten minste tussen wetenskaplikes wat erken dat onbewysbare voorveronderstellings 'n deurslaggewende rol in die beoefening van die wetenskap speel, deurgaans moontlik is. Ten slotte word in paragraaf 5 aangetoon dat daar ' $n$ verband tussen die waardes van die Grondwet, die uitoefening van owerheidsgesag en die ontwikkeling van 'n Suid-Afrikaanse reg-begrip bestaan.

\section{Onopgeloste probleem: wat is 'n reg?}

Sonder 'n reg-begrip (hierdie ietwat ongewone term word - in plaas van die meer intuïtiewe "regsbegrip" - vir die huidige doel gebruik om te onderskei tussen die begrippe van ' $n$ reg (right) en die reg (the law)) kan 'n hedendaagse regstelsel nie funksioneer nie. Twee redes daarvoor is dat regsverhoudinge tussen deelnemers aan die regsverkeer grootliks deur die afweging van regte en verpligtinge gereguleer word en dat die moderne staat, minstens sedert die einde van die agtiende eeu, daarvoor verantwoordelik gehou word om regte wat grondwetlik vir die burgery gewaarborg word, te respekteer en in stand te hou.

Hoewel niemand die bestaan van regte betwis of in twyfel trek nie, is daar geen eenvormige antwoord, ook in die Suid-Afrikaanse regswetenskap, beskikbaar op die vraag wat "n reg" is nie. Voorts bestaan die gebruik ook om regte in privaatregtelike verband heeltemal anders te benader as regte in die publiekreg.

In ons regstaal word die drieletterwoord "reg" dus in vele kontekste en verbindings aangewend: mensereg, fundamentele reg, subjektiewe reg, individuele reg, sosio-ekonomiese reg, prosessuele reg, ensomeer. Die vraag ontstaan nou, en dit is verstommend hoe selde dié soort vraag hoegenaamd geopper word, of 'n eenduidige betekenis van die woord - wat geldig is vir al die kontekste gekonstrueer kan word. Anders gestel, bestaan daar hoop daarvoor om met regverdiging te kan sê "'n reg is 'n reg is 'n reg"? Vermoedelik is daar in die gemoed van die meeste moderne mense 'n intuïtiewe konsepsie van die abstrakte reg-begrip, ongeag die konteks waarin dit verwoord word. Per slot van rekening is enige reg iets wat 'n mens opeis, waarop 'n mens aanspraak maak, wat vir 'n mens deur die reg beskerm word en vir die handhawing waarvan 'n mens jou op die staat kan beroep - veral die regsprekende (maar ook bepaalde uitvoerende) organe. 
Johan van der Vyver het in sy publikasieloopbaan aandag geskenk aan die problematiek van die aard van die reg vanuit sowel 'n algemeen-juridiese (maar privaatregtelik-gekleurde) perspektief as vanuit 'n menseregtelike (met vanselfsprekende publiekregtelike klem) perspektief. Hieronder word verwys na verskeie van sy publikasies wat rigtinggewend was in die ontplooiing van die SuidAfrikaanse regsleer oor sowel die subjektiewe reg as menseregte.

\section{Subjektiewe regte: protagonisme en antagonisme}

Die subjektiewe regsleer, wat onder die onmiskenbare invloed van die Calvinistiese leerstellinge van Dooyeweerd in die Suid-Afrikaanse regsleer ingevoer is (vergelyk die behandeling van W.A. Joubert se seminale bydrae in hierdie verband in Venter, 1985:99-103), het in veral die Afrikaanstalige regsliteratuur 'n diepliggende invloed uitgeoefen - veral in die dogmatiek van die privaatreg (Van Zyl en Van der Vyver, 1982:369-439, wat dikwels aangehaal is in werke oor privaatregtelike dissiplines: vgl. byvoorbeeld Sonnekus en Neels, 1994:6-19). Die essensie van hierdie benadering is te vinde in die konstruksie van 'n regsverhouding tussen alle regsubjekte met betrekking tot objekte waaraan waarde vir die reghebbendes juridies toegeken word. Die aard en inhoud van spesifieke subjektiewe regte word medebepaal deur die aard van die regsobjek en die positiewe regsnorme wat van toepassing is. Die inhoud van 'n subjektiewe reg word uitgedruk as 'n bevoegdheid, wat dui op dit wat die reghebbende regtens geoorloof is om met die betrokke regsobjek te doen.

Die skrywer van hierdie bydrae het in die tagtigerjare 'n poging aangewend om die subjektiewe regsleer bruikbaar te maak vir die verklaring en beskrywing van die publiekregtelike verhouding. 'n Belangrike motief daarvoor was om die leemte aan 'n publiekregtelike analise van die aard en inhoud van die verhouding tussen die staat en die burger aan te toon. Die destydse afwesigheid van grondwetlik-verskanste fundamentele regte in die Suid-Afrikaanse reg en die vaagheid van die idealistiese menseregteleer wat in die openbare publiekregtelike debat van dié era hoogty gevier het, het die saak aansienlik bemoeilik. Op dié poging was daar interessante reaksie, maar weinig entoesiasme. In die koorsagtigheid van die destydse debatte oor menseregte en die wêreldwye sensuur van Suid-Afrika weens die skending van menseregte het sommige kritici emosionele, in plaas van wetenskaplike, kommentaar gelewer (vgl. Venter, 1991). 'n Skrywer soos Wiechers, wat nie met die onderliggende teoretiese benadering saamgestem het nie, het egter wel aanklank gevind by die uitdrukking "publieke subjektiewe regte" as 'n voertuig vir die benoeming en konkretisering van menseregte (Wiechers, $1988: 255$ e.v.). Op publiekregtelike terrein was dit egter deurgaans onvermydelik dat die globale prominensie van menseregtedenke, nie veel ruimte gelaat het vir 'n nuwe teoretiese benadering tot regte in die publiekregtelike konteks nie. 
Afrikaanse skrywers se Engelstalige verduideliking van die subjektiewe regteteorie (toegepas op die privaatreg) het wel 'n invloed op die Engelstalige literatuur oor die onderwerp uitgeoefen (vgl. Van der Vyver, 1988), maar nie tot so 'n mate dat die subjektiewe regsteorie die algemene Suid-Afrikaanse leer geword het nie, al is dit soms anders voorgestel (bv. Church \& Hosten, 1995:543-547)

Suid-Afrikaanse bydraes deur Engelssprekende juriste tot die regtedebat het hoofsaaklik op Anglo-Amerikaanse bronne gesteun, sowel in die privaatregtelike konteks (Hahlo \& Kahn, 1968:76-90) as in die publiekregtelike konteks (bv. Corbett, 1979). In die privaatregtelike verband is gereeld melding gemaak van die bekende "leer" van Hohfeld, terwyl die algemene regsideële menseregteleer en die voorbeeld van die VSA benut is in die publiekregtelike konteks. Die aanwendbaarheid van Hohfeld se teorie in die publiekreg is in elk geval in die literatuur in twyfel getrek (bv. Cameron, 1964:157)

In die jongste jare het daar 'n soort ongeduld met die streng strukturering wat kenmerkend van regteteoriee is, kenbaar geword (vgl. byvoorbeeld Van der Walt, 1990). Die onderliggende redes vir hierdie ongeduld word nie altyd deur die ongeduldiges uitgespel nie, maar kan toegeskryf word aan byvoorbeeld 'n verwerping van die logika van die gekritiseerde teorie of terminologie (Slabbert, 1996), 'n ontevredenheid met die binding of onbuigsaamheid daarvan of 'n postmodernistiese liefde vir komplekse maar altyd hersienbare beredenering en afwysing van vaste normering en klassifikasie.

Die pluraliteit van teorieë en die afwesigheid van konsensus verleen aan protagoniste en antagoniste van die subjektiewe regteleer, en ook aan alle ander teoretici, vrye speelruimte. Aan die ander kant dien die voortdurende pragmatiese en positivistiese geneigdheid van die regspraktyk en -toepassing om teoretisering oor die aard en vorm van regte ten gunste van die "sekerhede" van normvoorskrifte te ignoreer, as afskrikmiddel en demotiveerder vir die regswetenskaplike wat na die fondamente van hierdie sluitstuk van die regdimensie van die werklikheid vra

\section{Menseregte en fundamentele regte}

In die gangbare menseregteteorieë bestaan daar 'n groot mate van begripsverwarring omdat wesenlik verskillende soorte regsfigure oor één boeg as 'menseregte' opgedis word. ... Dit spreek vanself dat die leerstuk van menseregte, om vir die positiewe regstelsels van die wêreld diensbaar te wees, die gepostuleerde menseregte in 'n juridies bruikbare vorm moet giet. ... Dat daar by die positivering van menseregte speelruimte vir variabiliteit bestaan, staan vas, maar dit is ewe seker dat die regsvormende orgaan in dié verband aan onveranderlike struktuurbeginsels gebonde is en daarom nie willekeurig kan optree nie (Van der Vyver, 1975:16-17). 
Francois Venter

Sedert hierdie woorde gepubliseer is (dit was feitlik twee dekades voordat grondwetlik-verskanste fundamentele regte hulle verskyning in die SuidAfrikaanse reg gemaak het), en veral oor die afgelope vyf jaar, het 'n fundamentele regteleer in Suid-Afrika begin ontwikkel. Dit was net moontlik omdat 'n aantal "gepostuleerde menseregte in 'n juridies bruikbare vorm" gegiet is. Die invoering van die proto-handves in 1993 en die Handves van Regte in 1996, het die behoefte aan nuwe abstrakte teoretisering oor die aard en bruikbaarheid van menseregte in die regstelsel drasties verminder. Aan die ander kant het teoretisering oor menseregte vir die Suid-Afrikaanse juris meer konkrete (in teenstelling met regsideële en regsfilosofiese) betekenis as voorheen verkry, aangesien groot dele van die eeue-oue menseregteleer vir die grondwetlike regtebedeling en die toepassing van fundamentele regte relevant geword het.

In die Suid-Afrikaanse konteks is in die kort tydperk van die gelding van grondwetlik-beskermde fundamentele regte heelwat akademiese en regterlike werk gedoen wat kan bydra tot 'n meer omvattende regteteorie. Natuurlik bestaan daar geen konsensus, of selfs 'n ontluikende konsensus daaroor nie konsensus oor regte kan ook nie verwag word nie, aangesien sienings oor wesensaspekte van die staat, die reg en owerheidsgesag onophoudelik sal bly verskil. Hierdie wesensaspekte is ten nouste verweef met mense se Weltanschauung.

Die aard van die ontwikkelende Suid-Afrikaanse leerstellings oor grondwetlike regte kan ten beste waargeneem word by die nate van die debat, dit wil sê oor die sake waaroor die menings die maklikste uiteenloop:

- die gelding van fundamentele regte in regsverhoudings waarby die staat nie regstreeks betrokke is nie;

- die beregbaarheid en afdwingbaarheid van grondwetlike regte op staatsprestasie, en

- die betekenis en uitwerking van die gelykheidsgebod.

In hierdie artikel kan die debat en ontwikkelende fundamentele regteleer nie in besonderhede beskryf word nie, maar, soos ook later weer vermeld word, moet die waardes wat in die Grondwet neergelê en verskans word, noodwendig as beginpunt van so 'n oefening dien.

In 'n besonder waardevolle onlangse Amerikaanse bydrae (Gordon, 1998), betrek Joy Gordon die vraag na die sin van die menseregtebegrip opnuut. Sy beskryf onder meer die ontwikkeling van die gangbare kontemporêre menseregtebegrip met verwysing na die Nürnbergverhore van 1946 se hantering van menseregte as meganisme om wandade te identifiseer (dus as moral trump) en die uitbreiding van die begrip na feitlik alle lewensterreine deur middel van die 
Verenigde Nasies se Universele Verklaring van Menseregte van 1948. In die proses beredeneer sy die kwesbaarheid van die onderskeid tussen die verbod op wandade en die inbreukmaking op politieke regte enersyds, en ekonomiese en sosiale regte andersyds, veral as daarvan uitgegaan word dat menseregte as minimale hulpbronne of voorwaardes vir menslike bestaan verstaan moet word:

... the standard notion of human rights is in some degree actually dangerous in that it invokes ethical principles that it claims are not only universal, but absolute. At the same time, because it implicitly asserts the most extreme moral claim possible, it is not concerned merely with which acts are wrong, but rather with distinction between absolute righteousness and absolute evil. It can provide - and has on certain occasions provided - a justification for doing violence or inflicting suffering, if these take place on behalf of 'human rights', much the way that claims of righteousness have justified the bloodiest acts of holy wars (Gordon, 1998:699).

'n Aktuele vraag wat Gordon na vore bring, is wat 'n mens eintlik het as jy 'n (mense)reg het? Daar is dikwels 'n skreiende gaping tussen die verlening van 'n reg wat as 'n absolute feitelike werklikheid geformuleer is, byvoorbeeld "almal is vry en gelyk", en die werklikheid, soos die ontoeganklikheid van remedies weens armoede. Sy kom uiteindelik ietwat moedeloos tot 'n versugting: "In the end I wonder if we aren't better off without any notion of absolute rights or moral trumps" (Gordon, 1998:790).

Die waarde van Gordon se bydrae is nie soseer in hierdie gevolgtrekking geleë nie, maar onder meer in die ontbloting van die tekortkominge in die geykte benadering tot die klassifikasie van regte. In hierdie verband verteenwoordig De Vos se bydrae (De Vos, 1997) 'n interessante Suid-Afrikaanse aanpak van die probleem om te onderskei tussen die burgerlike en politieke regte enersyds en die sosio-ekonomiese regte andersyds.

By die hantering van die spektrum van fundamentele regte word dikwels na verskillende kategorieë regte verwys. Die idee dat fundamentele regte in drie generasies geklassifiseer kan word (bv. Gordon, 1998:692) is aantreklik vir die doeleindes van 'n historiese beskrywing van die ontwikkeling van die moderne konsep van grondwetlike regte. As 'n funksionele klassifikasiemetode is dit egter minder effektief.

Of dit hoegenaamd nodig of nuttig is om fundamentele regte in kategoriee te klassifiseer, kan bevraagteken word. Per slot van rekening het alle fundamentele regte die gemeenskaplike kenmerke van verskansing deur die Grondwet, voorkeurwerking van die regte bo enige ander reg of regsreël en afdwingbaarheid daarvan deur die draers van die regte. Verder kan aangevoer word dat die kategorisering van fundamentele regte geensins aan hulle inhoud of werking sal verander nie. 
Aan die ander kant, wanneer 'n mens die Handves van Regte deurlees, word dit gou duidelik dat nie alle bepalings in die Handves grondwetlike regte tot stand bring en beskerm nie, en dat daar belangrike verskille tussen verskillende regte is. Hierdie verskille kan byvoorbeeld aspekte soos die volgende insluit: wie die draers daarvan is, wie of wat daardeur gebind word, wat die aard van die aansprake is wat daardeur aan die draers verleen word, wat die rol van die staat by die realisering van die regte is, die aanduiding dat sommige regte onder bepaalde omstandighede voorkeur bo ander regte moet geniet, ensomeer.

Wanneer 'n mens dus 'n sistematiese studie wil maak van die fundamentele regte wat in die Handves opgeneem is, word dit sinvol om 'n maatstaf te ontwikkel aan die hand waarvan regte weens hulle gemeenskaplike eienskappe bymekaar gegroepeer kan word ten einde 'n meer hanteerbare konseptuele greep daarop te kry. Dit is per slot van rekening tipies wetenskaplik om in die proses van ontleding ter wille van helder begrip te kategoriseer en te klassifiseer.

Geen klassifikasie van fundamentele regte kan waterdig of onveranderlik ontwerp word nie, aangesien ons hier met 'n komplekse, veelfasettige verskynsel werk. 'n Fundamentele reg is nie 'n eenvoudige, afgeronde grootheid nie, maar bly plooibaar, is onderhewig aan voortdurende ontwikkeling, afweging teenoor ander regte, toetsing aan die praktyk van die menslike samelewing, die regspleging, ensomeer. Dat 'n bepaalde fundamentele reg dus by meer as een sistematiese kategorie tuisgebring kan word, moet dus nie as verbasend beskou word nie. Dat verskillende klassifikasieskemas moontlik is, is dus ook nie verbasend nie.

Wanneer die "operasionele" bepalings van 'n handves ter syde gelaat word, bly die bepalings wat fundamentele regte as sodanig daarstel en verskans, dit is die hoofsaak van die handves, oor. Ter wille van 'n sistematiese analise van hierdie bepalings is dit nuttig om die fundamentele regte wat in die Handves voorkom, te kategoriseer.

So kan byvoorbeeld ten minste vyf kategorieë fundamentele regte geïdentifiseer word.

\section{- Normatiewe regte}

Die eerste daarvan is regte wat uitdrukking gee aan essensiële ideale van die samelewing en wat gevolglik meer as ander regte gesien kan word as normatief vir die betekenis van ander regte en ook vir ander regsreëls, ook die res van die bepalings van die Grondwet. Na hierdie groep regte kan verwys word as normatiewe regte. Hieronder ressorteer die reg op lewe (artikel 11), wat funderend is omdat lewe 'n voorvereiste is vir alle ander regte; regte met betrekking tot menswaardigheid (artikel 10) wat ooreenstem (maar nie identies is nie) met die hoogste kernwaarde waarop die Suid-Afrikaanse staat gefundeer 
is ingevolge artikels $1,7(1)$ en 39(1)(a), ensomeer, en regte op gelykheid (artikel 9) wat ook as sleutelwaarde in artikels $1,7(1)$ en 39(1)(a) vermeld word.1

\section{- Afweerregte}

'n Tweede kategorie is 'n groep regte wat gekenmerk word deur hulle verdedigende karakter en die feit dat hulle afdwingbaar is deur die draers daarvan om spesifieke individuele belange teen inbreukmaking te beskerm. $\mathrm{Na}$ hierdie kategorie kan kortom verwys word as afweerregte. Hoewel sommige van die regte wat hier primêr in party van die ander kategorieë geplaas word (soos regte met betrekking tot menswaardigheid) ook hieronder tuisgebring kan word, pas veral die volgende regte goed daarby in: regte op beskerming teen slawerny, knegskap en dwangarbeid (artikel 13); regte met betrekking tot privaatheid (artikel 14); regte op vryheid van uitdrukking (artikel 16); die regte op vryheid van beweging en bedryf (artikel 21) en die regte met betrekking tot eiendom (artikel 25).

\section{- Prosessuele regte}

'n Bundel fundamentele regte word gekenmerk deur die rol wat hulle vervul in prosedures en prosesse wat van owerheidswee in stand gehou word. Dit is ook regte wat die individu teen die staat kan opwerp in antwoord op dreigende prosedurele onreg. Hier kan van prosessuele fundamentele regte gepraat word, wat 'n aantal regte met betrekking tot die vryheid en sekerheid van die persoon (artikel 12) insluit; regte op regverdige administratiewe optrede (artikel 33); die regte ten aansien van toegang tot die howe (artikel 34); die kompleks van regte van gearresteerde, aangehoue en beskuldigde persone (artikel 35) en die regte op locus standi in fundamentele regtegeskille (artikel 38).

\section{- Gemeenskapsgeoriënteerde regte}

'n Reeks fundamentele regte het betrekking op die individu in die gemeenskap. $\mathrm{Na}$ hierdie kategorie kan verwys word as gemeenskapsgeorienteerde fundamentele regte. Onder hierdie regte kan daar twee subkategorieë onderskei word, naamlik regte wat primêr ter sprake is in die konteks van die burgerlike gemeenskap (dit wil sê waar die staat nie regstreeks betrokke is nie) en dié wat in staatsverband van besondere belang is.

1 Die waardebepalende voorskrifte van die Grondwet, waarvan artikels $1,7(1)$ en 39(1) onder die belangrikstes tel, vermeld telkens benewens menswaardigheid en gelykheid ook nog vryheid. Anders as eersgenoemde twee waardes, word laasgenoemde egter nie in die Handves tot 'n spesifieke fundamentele reg omvorm nie. Die begrip "vryheid" kom egter op verskeie plekke in die Handves in ander verbindings voor, byvoorbeeld in frases soos "genieting van alle regte en vryhede" (a 9(2)), "vryheid en sekerheid van die persoon" (a 12), "vryheid van godsdiens, oortuiging en mening" (a 15), ensovoorts. 
By eersgenoemde subkategorie vind ons die regte met betrekking tot die vryheid van godsdiens, oortuiging en mening (artikel 15), asook vryheid van assosiasie (artikel 18); die vryheid van bedryf, beroep en professie (artikel 22); regte in die verband van arbeidsverhoudinge (artikel 23); die regte van kinders (artikel 28); sommige van die regte in verband met onderwys (artikel 29); taal- en kultuurregte (artikel 30), en regte van kultuur-. godsdiens- en taalgemeenskappe (artikel 31).

Wat die tweede subkategorie van die gemeenskapsgeoriënteerde fundamentele regte betref, naamlik dié wat in die staatsgemeenskap ter sake is, kan die volgende daarby gereken word: regte met betrekking tot vergadering, betoging, linievorming en petisie (artikel 17); die sogenaamde politieke regte (artikel 19), en die reg om nie burgerskap ontneem te word nie (artikel 20).

\section{- Fundamentele regte op staatsprestasie}

'n Laaste kategorie word daardeur gekenmerk dat die betrokke regte aan die draers daarvan aanspraak gee op positiewe optrede van die kant van die staat. Dit kan fundamentele regte op staatsprestasie genoem word. Hieronder ressorteer regte met betrekking tot die omgewing (artikel 24); regte met betrekking tot behuising (artikel 26); regte op toegang tot gesondheidsorg, voedsel, water en maatskaplike sekerheid (artikel 27); regte op onderwysvoorsiening (artikel 29) en regte op toegang tot inligting (artikel 32).

Soos vroeër aangedui is, kan nóg hierdie, nóg enige ander klassifikasie van fundamentele regte as absoluut geld, of beklee word met normatiewe betekenis. Klassifikasie is hoofsaaklik bruikbaar vir analitiese doeleindes. Die regspraak en akademiese debat veral oor die sogenaamde sosio-ekonomiese regte bring juis die beperkings van die onderskeid tussen dié kategorie en "burgerlike en politieke regte" na vore. Dieselfde kan van ander klassifikasies verwag word.

\section{Is 'n enkele, omvattende "reg"-begrip moontlik?}

Die geykte persepsie dat 'n grens tussen privaatregtelike en publiekregtelike regte gehandhaaf moet word, moes onvermydelik as gevolg van die invoering van 'n fundamentele regtebedeling verander word. Die onvermydelikheid hiervan is dadelik duidelik wanneer nagegaan word watter regsobjekte (in die idioom van die subjektiewe regsleer) in die Handves van Regte ter sprake kom: persoonlikheidsgoedere (ten minste in artikels 7, 10, 12, 21(1) en 36(1)); privaatheid (artikel 14) (vergelyk Neethling, 1976:287-293 se konstruksie van privaatheid as regsobjek); eiendom (artikel 25 - hieronder meer hieroor); immateriële goedere (artikel 16(1)) en prestasie (artikels 26-29).

Die penetrasie van die terrein van die privaatreg deur grondwetlike norme, veral dié wat deur die Handves geskep is, is sedert 1994 dikwels aan die orde. Dit kom op ten minste drie maniere na vore: eerstens deurdat die balansering van 
Regte, gesag en waardes

mededingende fundamentele regte onvermydelik in sekere soorte geskille tussen individue ter sprake kom, byvoorbeeld in lastergedinge (vergelyk bv. Van Heerden, 1996 en die regspraak daar aangehaal); tweedens deurdat daar regstreekse grondwetlike ingryping op tradisioneel privaatregtelike verhoudinge in sekere grondwetlike bepalings voorkom, byvoorbeeld artikel 23 (arbeidsverhoudinge) en artikel 28 (kinders); en derdens die kwessie van die regstreekse en onregstreekse toepassing van die bepalings, gees, strekking en oogmerke van die Handves op regsverhoudinge waarin die staat nie 'n party is nie en op die gemenereg en gewoontereg (artikels 8, 9(4) en 39(2)).

Die grondwetlike hantering van eiendom (artikel 28 van die 1993 Grondwet en artikel 25 van die 1996 Grondwet) het 'n hoogs interessante, besonder verfynde en uitdagende wetenskaplike ondersoekproses ontketen wat gekenmerk word deur grondige historiese en filosofiese ontleding en besinning. Oor hierdie tema het die jubilaris amper 'n dekade voor die nuwe grondwetlike bedeling 'n bydrae gelewer (Van der Vyver, 1985). 'n Primêre vraag wat ondersoek word, is wat eiendom (alles) behels (vgl. Kroeze, 1997 en die bronne deur haar aangehaal veral die veelvuldige en indringende bydraes in hierdie verband van A.J. van der Walt). Hierdie ondersoek na eiendom veroorsaak dat die sakereg nooit weer sal wees wat dit in voor-grondwetlike tye was nie, en bring mee dat eiendomsreg, wat voorheen as relatief eenvoudige, klinies-ontleedbare reg op stoflike sake verstaan is (byvoorbeeld Hall, 1971:25-47), nou omgewe is van lands- en regspolitieke komplikasies.

Hierbo is reeds verwys na die pluraliteit van regteteorieë wat lank reeds in die privaatreggesentreerde debat bestaan, asook na die afwesigheid van konsensus of verwagting van eenstemmigheid oor die ontluikende Suid-Afrikaanse fundamentele regteleer. $\mathrm{Na}$ my mening is dit wel denkbaar, en ter wille van sinvolle wetenskaplike en praktykskommunikasie wenslik om 'n basiese SuidAfrikaanse konstruksie van wat "n reg" is, te ontwikkel. Per slot van rekening staan die begrip so sentraal in die regspraktyk en -wetenskap en vervul sodanige sentrale rol in ons regskommunikasie, dat verwarring oor die basiese betekenis van die woord die integriteit van die stelsel as sodanig sou kon bedreig. Hierdie is natuurlik geen nuwe probleem nie (vgl. Hahlo \& Kahn, 1968:80). Oor die algemeen is dit myns insiens darem waarskynlik dat algemeen aanvaar kan word dat die essensiële omgangsbetekenis van "reg" soos volg uitgedruk kan word: 'n reg dui op 'n aanspraak van die een of ander aard wat die reghebbende het, wat die reghebbende ingevolge die toepaslike regsnorme kan opeis en desnoods afdwing.

Om die ontwikkeling van algemene eenstemmigheid oor veel meer as so 'n basiese omskrywing te verwag, is egter onrealisties. Die rede daarvoor is dat die dieper dimensies van die reg-begrip regstreeks verband hou met vrae oor die beskerming en afdwinging van regte, wat op 'n kort roete lei na vrae oor die aard en herkoms van staatsgesag, wat weer die hele kwessie van die algemene 
regsbegrip en die staatsbegrip na vore bring. Die beredenering verloop onwillekeurig min of meer soos volg:

As ek 'n reg het en uit hoofde daarvan op iets aanspraak maak, wat staan my te doen as iemand in die weg van die voldoening aan my aanspraak staan? In ons geordende samelewing waar eierigting in beginsel nie geoorloof is nie, moet ek my tot 'n owerheidsinstelling kan wend om my aanspraak teenoor my teenstanders af te dwing. Vir enige instelling of persoon om die teenstanders te dwing om my aanspraak te respekteer en dienooreenkomstig op te tree, is dit nodig om oor gesag te beskik. In die hedendaagse gemeenskap berus hierdie gesag by die staat en word dit deur sy regsprekende, uitvoerende en wetgewende organe uitgeoefen.

Gangbaar is die beredeneringsroete tot hier nie juis omstrede nie, maar wanneer verdere analise volg, skei die weë dramaties. Natuurlik kom die standpunt voor dat verdere analise onnodig is, aangesien die bestaan van staatsgesag ' $n$ empiriese, onbetwisbare gegewe is. So 'n standpunt is na my mening erg oppervlakkig en getuig van 'n verwaterde, meganiese wetenskapsbenadering. (Dit kan vergelyk word met 'n aptekersassistent wat pille volgens voorskrif aftel en uitreik sonder enige kennis van die farmakologiese samestelling of werking daarvan.) Indien daar, soos hier, daarvan uitgegaan word dat standpunte en gevolgtrekkings se wetenskaplike kwaliteit afhanklik is van die mate waartoe die standpunt verdedig kan word vanuit die wetenskaplike se oortuigings aangaande die tersaaklike onderliggende onbewysbare aannames, kan die bestaan en aard van die staat se gesag nie maar aanvaar word as een van die vanselfsprekende gegewens waarmee die juris moet werk nie. Die meeste wetenskap word natuurlik bedryf sonder eksplisiete vermelding of verantwoording van die onbewysbare aannames van die wetenskaplike. Dit is egter op die snypunte van meningsverskil oor standpunte of bevindings as wetenskaplike resultate, waar die kwaliteit van wetenskaplikheid, oftewel deurdagtheid tot by die wortels, ontbloot word.

Die beantwoording van twee kernkwessies wat vir die onderhawige tema tersaaklik is, is so wesenlik verweef met uitgangspunte en buitewetenskaplike oortuigings, dat eenstemmigheid daaroor nooit bereik sal kan word nie, naamlik die vrae wie of wat die staat is, en wat die aard en herkoms van owerheidsgesag is.

Die klassieke (sewentiende- en agtiende-eeuse) eksponente van die sosiale verdragsteorie, Hobbes, Locke en Rousseau (tussen wie daar ook aksentverskille was), se denke het weens die aanvaarding daarvan tydens die Amerikaanse en Franse staatsvorming aan die einde van agtiende eeu, 'n kragtige invloed op die moderne regs- en staatsdenke uitgeoefen. Die idee dat die mens in sy voorstaatlike natuurtoestand oor onbeperkte, maar onbeskermde, regte beskik, maar die beskerming en beperking daarvan by die totstandbrenging van die staat deur die algemene wil aan die staat opdra, regverdig in hierdie benadering 
tegelyk die legitimering en die beperking van owerheidsoptrede (Gordon, 1998:741-745). Die ontsaglike en blywende invloed van die verdragsteorie is verbasend as ' $n$ mens voor oe hou dat dit op 'n fiktiewe, nie-historiese, gekonstrueerde verloop van gebeure berus en ook dat dit inherent teenstrydig is Hierdie teenstrydigheid is onder andere deur Jolowicz (1963:93) treffend uitgewys:

If there was in truth no contract then it is merely useless fiction to base state and law upon it. The idea of the social contract is really an attempt to justify law by law, and this is logically inadmissable ... If law is to be justified it must find its justification in something outside itself

In die huidige tydsgewrig, wat toenemend as "postmodernisties" getipeer word, word die liberale tradisie toenemend onder druk geplaas:

The first gesture of the deconstructive resistance to the language of constitutional democracy, is to remind us of its Hobbesian origins. Deconstruction reminds us that the language of constitutional democracy that the works of Locke, Rousseau, Kant, Hart and Dworkin would refine in the course of four centuries, pivots on the imposition of order on a social reality that naturally evinces no such order in itself. That legal order does not reflect the intrinsic order of society, is most evident from the fact that it cannot be maintained without the constant threat of violent enforcement, as the work of Robert Cover explains so poignantly (Van der Walt, 1998:78-79).

Desnieteenstaande bly die liberale konstruksie van die sosiale verdrag besonder invloedryk. Daar is natuurlik ook vele ander opvattings, maar dit is nie hier moontlik om op ander verklarings van owerheidsgesag, die staat en die reg in te gaan nie (Gordon, 1998:745-762 voorsien 'n behendige beskrywing van die kritiek op die verdragsteorie deur empirisiste soos Hume en Bentham, moderne liberaliste soos Gewirth en Dworkin en van Karl Marx)

Die ervaring van die eeue laat blyk dat, ongeag die heftigheid, logika of briljantheid van die deklamering van standpunte oor hierdie onderwerpe, eenstemmigheid daaroor net tot stand gebring kan word onder mense wat soortgelyke lewensbeskoulike uitgangspunte deel. Die standpunte en houdings oor hierdie voorvrae is te diep in voorveronderstellings en geloofsoortuigings gewortel om eenstemmigheid daaroor na te streef. Dit kan ook só gestel word: die onmoontlikheid om eenstemmigheid oor die fundamentele vraag na die bron en bestaansrede vir owerheidsgesag te vind, terwyl die antwoord op dié vraag die toetssteen is vir die houdbaarheid van 'n bepaalde reg-begrip, maak van dié toetssteen 'n struikelblok vir iemand wat eenstemmigheid oor die saak nastreef.

Dit is, soos hierbo aangedui, heeltemal moontlik om 'n meganiese beskrywing van buite van die die reg-verskynsel te gee. So 'n beskrywing bring 'n mens egter nie ver as jy antwoorde moet soek op vrae soos die volgende nie: waarom is die reg-begrip so 'n integrale element van die reg as normstelsel? Wat is die 
verband tussen fundamentele regte en menseregte en is menseregte aangebore en onvervreembaar? Watter regspolitieke oorwegings geld by die regverdiging van die beperking van regte? ensomeer.

Regswetenskaplikes wat meen dat die antwoord op die herkoms van owerheidsgesag, die verklaring van die aard van 'n reg en 'n omvattende regteorie op 'n waardevrye uitgangspunt gefundeer kan word, sal vanselfsprekend nie die skrywer hiervan se benadering tot die probleem, wat gebaseer is op 'n Skrifgefundeerde uitgangspunt, kan aanvaar nie (Venter, 1985:131-148). Dit is nietemin geformuleer in die veronderstelling dat dit ten minste vir regswetenskaplikes wat die invloed van lewensbeskoulike oortuigings op 'n mens se wetenskapsbeoefening erken, 'n bruikbare wetenskaplike gespreksgrondslag oor hierdie tema kan bied. Die essensie daarvan is soos volg:

Die reg (in die sin van 'n stelsel van objektiewe norme) is onontbeerlik vir die ordening van die staatsgemeenskap. Die staat kom tot stand deur regswerking, en is tegelyk verantwoordelik vir die instandhouding van die regstelsel. (Hierdie gegewe is net ' $n$ sirkelredenasie indien aangedring word op die identifisering van 'n historiese oermoment toe die staat tot stand gekom het 'n dilemma wat die sosiale verdragsteorie met 'n fiksie probeer oplos.) Owerheidsgesag, die kompetensie van die staat om dwingend op te tree, is noodsaaklik vir die instandhouding van die regsorde. Owerheidsgesag word menslik gesproke regtens begrond en die geldige uitoefening daarvan kan in die regstaat net in ooreenstemming met die reg geskied. Die universele en noodwendige bestaan van gesag in 'n regsgemeenskap is, so blyk dit uit die Skrif (bv. Romeine 13:1-7), 'n skeppingsgegewe.

Buite-om die juridiese normering daarvan is God die enigste bron van staatlike owerheidsgesag. Omdat God die bron van alle gesag is, is gesag altyd tot Hom herleibaar. Die wese van gesag as omvattende begrip kan nie werklik verstandelik begryp word nie omdat dit so kompleks en veelsydig is. Uit 'n menslike oogpunt kan ons dit alleen só verklaar dat gesag tot God se wese behoort en derhalwe in hierdie bedeling nie ten volle kenbaar is nie. Net soveel van sy wese as wat God aan ons openbaar, kan ons begryp; soveel van die konsep 'gesag' as wat skeppingsmatig vir menslike hantering bestem is, kan ons onder woorde bring. Juis omdat gesag die gesagsdraer deur Goddelike beskikking toekom (bv. Efesiërs 1:19-22), is die verkryging daarvan nie iets waaroor die gesagsdraer self finaal kan beskik nie, al sou die ontstaansbron daarvan agnosties of godslasterend misken word. Daardeur word die gesagsdraer natuurlik nie van die verantwoordelikheid onthef om geregtigheid en 'n regverdige orde deur die regmatige uitoefening van die gesag na te streef nie. Om die menslike hantering van die gesag van die staat verstandelik verstaanbaar te maak, moet van juridiese taal gebruik gemaak word: in die skeppingsorde is daar dus voorsiening vir die moontlikheid om iets van die (onverstaanbare) Goddelike beskikking oor owerheidsgesag verstaanbaar uit te druk - en wel in juridiese terme. 
'n Probleem met die regswetenskaplike hantering van owerheidsgesag is egter dat daar te maklik volstaan word met die beskrywing en analise van die regsnorme wat owerheidsgesag reguleer, sonder om te vra na die begronding van die owerheidsgesag buite-om die juridiese normering wat voorhande is. Wanneer so te werk gegaan word, word algemeen aanvaarde "geleerdheid" en regspraktyk beoefen, maar in wese is dit bloot ' $n$ meganiese ordening van reels asof die betrokke stel reêls die enigste werklikheid en waarheid verteenwoordig en nie maar bloot veranderlike, menslike voorskrifte is nie.

Die wete dat eenstemmigheid oor die herkoms, aard en begronding van gesag in die staat ' $n$ futiele droom is, is grootliks bevrydend, omdat die uiteensetting van 'n eie standpunt daaroor gerig kan wees aan diegene met 'n beskouing van wetenskapsbeoefening wat die rol van voorveronderstellings erken. Rasionaliste en andere wat daarvan uitgaan dat die volle waarheid ontdek kan word deur voldoende individuele of kollektiewe intellektuele inspanning, mag hierdie standpunt as parogiaal of selfs ontvlugtend afmaak. Natuurlik bestaan die gevaar dat die wete dat die hele wêreld nie oortuig kan word van jou standpunt nie, kan lei tot selftevredenheid en 'n beterweterige verwerping van alle analises wat op ander as die eie uitgangspunt gebaseer is. Dit word nie hier voorgestaan nie: net soos die waarnemer en kommentator ander standpunte en analises aan sowel sy eie uitgangspunte as aan die inherente logika en standhoudendheid van die standpunt moet meet, moet hy bereid wees om sy standpunte en analises wetenskaplik te laat meet deur andere wat nie sy uitgangspunte deel nie. Uit-dieheup-verwerping van ' $n$ standpunt omdat dit op voorveronderstellings berus wat 'n mens nie deel nie, is op sigself verwerplik. Dit impliseer 'n dissipline wat 'n mens van wetenskaplikes oor die algemeen kan verwag.

\section{Die verband tussen regte, gesag en waardes}

Die 1996 Grondwet is 'n besonder waardebelade dokument. Dit blyk onder meer uit die feit dat artikel 1 daarvan swaar verskans is (artikel 74(1)) en soos volg lui:

Die Republiek van Suid-Afrika is een, soewereine, demokratiese staat gegrond op die volgende waardes:

(a) Menswaardigheid, die bereiking van gelykheid en die uitbou van menseregte en vryhede.

(b) Nie-rassigheid en nie-seksisme.

(c) Die oppergesag van die grondwet en die heerskappy van die reg.

(d) Algemene stemreg vir volwassenes, 'n nasionale gemeenskaplike kieserslys, gereelde verkiesings en 'n veelparty-stelsel van demokratiese regering, om verantwoordingspligtigheid, 'n responsiewe ingesteldheid, en openheid te verseker. 
Elders (Venter, 1998) is gestel dat die bepalings oor grondwetlike waardes 'n bepaalde hiërargie van die waardes laat blyk, naamlik menswaardigheid as primêre kernwaarde, gelykheid en vryheid as ondersteunende kernwaardes, demokrasie, oppergesag van die Grondwet en die heerskappy van die reg as strukturele en prosedurele waardes en nie-rassisme en nie-seksisme as waardes wat afgelei is van gelykheid.

Die inleidende bepaling van die Handves van Regte (artikel 7(1)) lê 'n duidelike verband tussen die waardes en fundamentele regte deur te bepaal dat die Handves "die demokratiese waardes van menswaardigheid, gelykheid en vryheid" bevestig.

Voorts vereis artikel 7(2) van die staat om "die regte in die Handves van Regte [te] eerbiedig, beskerm, bevorder en verwesenlik". Hierdie bepaling is een van verskeie wat die staat se onderworpenheid en gebondenheid aan die Grondwet en die reg oor die algemeen vereis (vgl. onder meer artikels $2,8(1)$ en 237), wat ook beteken dat die uitoefening van die gesag van die staat onderhewig is aan die bepalings en die waardes van die Grondwet.

Ter aanvulling van wat hierbo oor owerheidsgesag en die herkoms daarvan gesê is, kan die voorskrifte en waardes van die Grondwet as menslik-verstaanbare en hanteerbare regsmaatstawwe beskou word wat die uitoefening van owerheidsgesag in Suid-Afrika reguleer. Hier onstaan egter weer 'n fundamentele vraag wat nie met 'n bloot rasionele aanslag opgelos kan word nie, naamlik wat die betekenis en inhoud is wat aan die grondwetlike waardes toegeken moet word. So sal menswaardigheid byvoorbeeld uit 'n kommunitaristiese perspektief 'n ander inhoud en klem ontvang as uit 'n liberalistiese perspektief. Uit die Skrifgelowige juris se perspektief weer sal dit nie humanisties beklemtoon word nie, maar gesien word as deel van die erkenning van die soewereiniteit van God.

Die vraag na die verband tussen regte, gesag en waardes, wat 'n mens weer onwillekeurig teruglei na onbewysbare uitgangspunte van persoonlike oortuiging, kan nie hier verder gevoer word nie. Dit sal egter in die verdere ontwikkeling van die reg-begrip, van 'n spesifiek Suid-Afrikaanse staats- en owerheidsgesagsbeskouing en by die inhoudgewing van die grondliggende waardes van die Grondwet, met sekerheid verdiskonteer moet word.

\section{Bibliografie}

CAMERON, J.T. 1964. Two Jurisprudential Case Notes. The Juridical Review. 155-162

CHURCH, J. \& HOSTEN, W J. 1995. Private Law - Law of Persons. Chapter 5. (In Hosten, W.J. et al. Introduction to South African Law and Legal Theory. 2e uitg. Durban Butterworths. p. 542-576.)

CORBETT, M.M. 1979. Human Rights: the Road Ahead. South African Law Journal, 96(2): 192-202

Koers 64(2 \& 3) 1999:157-172 
DE VOS, P. 1997. Pious Wishes or Directly Enforceable Human Rights? Social and Economic Rights in South Africa's 1996 Constitution. South African Journal of Human Rights, 13(1):67.

GORDON, J. 1998. The Concept of Human Rights: the History and Meaning of Its Politicization. Brooklyn Journal of International Law, XXIII (3):691-791

HAHLO, H R. \& KAHN, E. 1968. The South African Legal System and Its Background. Kaapstad : Juta

HALL, C.G. 1971. Maasdorp's Institutes of South African Law. Volume II. 9e uitgawe Kaapstad : Juta.

JOLOWICZ, H.F 1963. Lectures on Jurisprudence. London

KROEZE, I.J. 1997. Between Conceptualism and Constitutionalism: Private Law and Constitutional Perspectives on Property. Pretoria : UNISA. (LL.D.-thesis.)

NEETLING, J. 1976. Die reg op privaatheid. Pteroria : UNISA. (LL.D.-proefskrif)

SLABBERT, M J.C. 1996. Die aard van juridiese regte. Tydskrif vir Hedendaagse RomeinsHollandse Reg, 59(3):412-424.

SONNEKUS, J.C. \& NEELS, J.L 1994. Sakereg vonnisbundel. 2e uitgawe Durban : Butterworth.

VAN DER VYVER, J.D. 1975. Die beskerming van menseregte in Suid-Afrika Kaapstad : Juta.

VAN DER VYVER, J.D. 1985. Ownership in Constitutional and International Law. Acta Juridica. 119-146.

VAN DER VYVER, J.D. 1998. Expropriation, Rights, Entitlements and Surface Support of Land. South African Law Journal, 105(1):1-16

VAN DER WALT, A.J. 1990. The Doctrine of Subjective Rights: A Critical Appraisal from the Fringes of Property Law. Tydskrif vir Hedendaagse Romeins-Hollandse Reg, 53(3) 316-329.

VAN DER WALT, J. 1998 The Language of Jurisprudence from Hobbes to Derrida (the latter's quest for an impossible poem Acta Juridica, 61-96.

VAN HEERDEN, C. 1996 Die invloed van die Grondwet op die bewyslas in die lasterreg: 'n sivielprosesregtelike oorsig. Tydskrıf vir die Suid-Afrikaanse Reg, 4:775-783

VAN ZYL, F.J \& VAN DER VYVER, J.D. 1982 Inleiding tot die Regswetenskap. Durban Butterworth.

VENTER, F. 1985. Die publiekregtelike verhouding. Durban : Butterworths

VENTER, F. 1991 Die publieke subjektiewe reg - 'n voorraadopname. Tydskrif vir Hedendaagse Romeins-Hollandse Reg, 54(3):349-366

VENTER, F. 1998 Die betekenis van die bepalings van die Grondwet: die aanhef en Hoofstuk 1. Vol. 1. Potchefstroomse Elektroniese Regsblad In die Internet te vinde by http://www.puk ac.za/lawper/tydskrif/1998vl.html

WIECHERS, M. 1988. Die publieke subjektiewe reg. (In Strauss, S A red Huldigingsbundel vir W.A. Joubert Durban : Butterworths p. 270-291.) 